\title{
Classical swine fever virus induces activation of plasmacytoid and conventional dendritic cells in tonsil, blood, and spleen of infected pigs
}

\author{
Agnès JAMIN $^{1,2}$, Stéphane GorIN ${ }^{1}$, Roland CARIOLET ${ }^{3}$, \\ Marie-Frédérique LE POTIER ${ }^{1}$, Gaëlle KUNTZ-SIMON ${ }^{1 *}$ \\ ${ }^{1}$ French Agency for Food Safety (AFSSA), Poultry and Swine Research Laboratory, Swine Virology \\ Immunology Unit, BP 53, 22440 Ploufragan, France \\ ${ }^{2}$ Present address: Institut National de la Recherche Agronomique (INRA), UMR Systèmes d'Élevage, Nutrition \\ Animale et Humaine, 35590 Saint-Gilles, France \\ ${ }^{3}$ French Agency for Food Safety (AFSSA), Poultry and Swine Research Laboratory, Section of Healthy Pig \\ Production and Experimentation, BP 53, 22440 Ploufragan, France
}

(Received 5 April 2007; accepted 21 August 2007)

\begin{abstract}
Classical swine fever virus (CSFV) compromises the host immune system, causing indirect leucopoenia and disruption of in vitro T cell stimulation capacity. In order to explore the potential role of dendritic cells (DC) in such phenomena, the activation of conventional DC (cDC) and plasmacytoid DC $(\mathrm{pDC})$ in blood and secondary lymphoid organs of infected pigs was investigated in the early time course post-inoculation (pi), together with viral components dissemination and cytokine production in serum. Whereas CD11R1 $1^{+} \mathrm{CD} 172 \mathrm{a}^{+} \mathrm{cDC}$ frequencies were markedly reduced in blood and spleen, analysis of $\mathrm{CD} 4^{+} \mathrm{CD} 172 \mathrm{a}^{+}$pDC numbers revealed a rapid turn-over of this DC subset in tissues pi. Both subsets matured and were activated after infection, as demonstrated by down-regulation of CD1a, up-regulation of the co-stimulation molecule CD80/86 and expression of cytokines. cDC essentially expressed tumor necrosis factor alpha (TNF- $\alpha$ ) and interleukin (IL)-10, whereas pDC produced alpha interferon (IFN- $\alpha$ ) and IL-12. IFN- $\alpha$ and TNF- $\alpha$ productions revealed an enhancement of innate anti-viral immune responses. Detection of antigen activated B lymphocytes in tonsil T-cell areas at $72 \mathrm{~h}$ pi, subsequently to the transient translocation of the viral E2 protein within germinal centres at $48 \mathrm{~h}$ pi, indicates the initiation of humoral response. This response was also evidenced by an important IL-10 production in serum one week pi. IL-12 expression in organs, as well as transient detection of IL-18 and IFN- $\gamma$ in serum, reflected the initiation of cellular immune responses. However, the uncommonly high levels of TNF- $\alpha$ and IFN- $\alpha$ produced by DC and measured in serum early post-infection, together with IL-10 expression in spleen, could play a role in the disruption of immune system cells, either inducing apoptosis or impairing DC functionalities themselves.
\end{abstract}

antigen presenting cells / secondary lymphoid organs / interferon / E2 antigen / pestivirus

\section{INTRODUCTION}

Classical swine fever virus (CSFV), a member of the genus Pestivirus within the Flaviviridae family, is a small, enveloped positive RNA virus [45]. Strains of high virulence cause a devastating disease in pigs, characterized by high fever, hemorrhagic lesions and high mortality [25]. CSFV can efficiently evade and compromise the host immune system, causing

\footnotetext{
* Corresponding author: g.kuntz.simon@afssa.fr
}

lymphoid organ atrophy, thrombocytopenia, granulocytopenia, and severe lymphopenia, particularly in B cells, due to apoptosis and necrosis of uninfected lymphocytes [36, 40, $41,44]$. Additionally, in vitro studies showed that uninfected $\mathrm{T}$ cells isolated from CSFVinoculated pigs lack their in vitro stimulation capacity [34].

Intending to explain immunosuppression mechanisms, recent studies investigated dendritic cell (DC) activation following an 
infection with CSFV. Indeed, DC are specialized antigen-presenting cells (APC) that bridge innate and adaptive immune systems with the unique capacity to initiate primary Tcell responses and efficiently stimulate memory responses [5]. Thus, their dysfunction may play a role in disruption of host immune responses. Previous reports concerned infection of monocyte-derived DC (mo-DC) and bloodisolated natural interferon (IFN) producing cells (NIPC), i.e. plasmacytoid DC (pDC). It was shown that CSFV replicates in mo-DC without cytopathological effect but prevents their activation and thereby the secretion of IFN- $\alpha$, tumor necrosis factor (TNF)- $\alpha$, interleukin (IL)-6, IL-10 and IL-12 [4, 13]. CSFV also blocks mo-DC maturation by inhibiting MHC-II up-regulation, although these cells remain able to present E2 viral envelop glycoprotein to cytotoxic T lymphocytes [14]. Similarly, CSFV replicates in NIPC [4]. However, unlike mo-DC, in vitro infected NIPC secrete large amounts of IFN- $\alpha$. To date, these in vitro findings could not be correlated to observations made in infected animals. Interestingly, high serum levels of IFN- $\alpha$ were recently found during the acute phase of CSF [43]. They were statistically correlated to the lymphocyte depletion, thus a relationship between both events was hypothesized, supported by the known adverse haematological effects of high IFN- $\alpha$ doses in vivo [3]. The authors reported that the infection also induces a progressive depletion of NIPC in blood, and thus suggested that IFN- $\alpha$ expression does not occur in the peripheral blood but in the lymphoid tissue [43].

In a previous work, we showed that swine secondary lymphoid organs and blood contained two distinct DC subsets [23]. One subset is composed of CD172 $\mathrm{a}^{+} \mathrm{CD} 11 \mathrm{R} 1^{+}$ cells that correspond to conventional DC $(\mathrm{cDC})$, whereas the other one is composed of $\mathrm{CD} 172 \mathrm{a}^{+} \mathrm{CD} 4^{+}$cells that correspond to pDC. In the steady state, $\mathrm{cDC}$ and pDC reside in $\mathrm{T}$ cell areas of secondary lymphoid organs and most of them are immature, as revealed by CD1a expression and lack of the co-stimulation molecule CD80/86. They express basal levels of TNF- $\alpha$, IL-12, IL-10 and
IFN- $\alpha$ at the steady state, the rates depending on the nature and location of producing cells. In this study, we intended to further explore interactions between CSFV and DC in infected pigs. DC activation was investigated (i) in the tonsil, the primo-site of infection, (ii) in blood, that gives greater place to leukocyte migration than lymph in the pig, (iii) in the spleen, a secondary lymphoid organ of importance due to its ability to filter the leukocyte containing blood, especially after infections [8]. We report findings about variations in DC frequency, location, phenotype and cytokine expressions in the early time course post-inoculation. Together with virus dissemination in tissues and cytokine production in serum, these data lead to new hypotheses on the role of DC subsets in host systemic immune response after CSFV infection.

\section{MATERIALS AND METHODS}

\subsection{Antibodies}

$\mathrm{mAb}$ against pig cell surface molecules CD1a (clone \# 76-7-4), CD4 (clone \# 74-12-4), CD21 (clone \# BB6-11C9), CD172a (porcine panmyeloid cell marker SWC3, clone \# 74-22-15A) were obtained from Southern Biotechnology Associates (Birmingham, USA). Anti-human CD80/86 (hCTLA-4-muIg fusion protein) was from Ancell (Bayport, USA). All these mAb were conjugated with FITC or red-phycoerythrin (RPE) or biotin. Anti-porcine CD11R1 mAb (clone \# MIL4) from AbDSerotec (Martinsried, Germany) was conjugated with FITC using the FluoReporter FITC Protein Labeling Kit (Invitrogen, Carlsbad, USA). Two mAb against porcine IFN- $\alpha$ (clone \# F17 and clone \# K9), mAb against IL-12 (clone \# 116219), biotinylated anti-porcine IL-12 polyclonal $\mathrm{Ab}$ (BAF912) and biotinylated anti-porcine TNF- $\alpha$ polyclonal Ab (BAF690) were from R\&D Systems (Minneapolis, USA). Biotinylated anti-porcine IL$10 \mathrm{mAb}$ (clone \# 945A1A926C2) was from Biosource (Camarillo, USA). Anti-porcine IFN- $\alpha$ $\mathrm{mAb}$ (clone \# F17) was biotinylated using the BiotinTag Micro Biotinylation Kit (Sigma-Aldrich, St. Louis, USA). FITC-conjugated $\mathrm{mAb}$ against CSFV E2 glycoprotein (clone \# F34113) was from Euroclone (Pero, Italy) and $\mathrm{mAb}$ against pestivirus NS3 protein (clone \# BVD-C16) was kindly provided by Dr I. Greiser-Wilke (School of Veterinary Medicine, Hannover, Germany). Streptavidin 
coupled to RPE-cyanin-5, RPE-conjugated polyclonal goat $\mathrm{F}(\mathrm{ab})_{2}$ anti-mouse Ig and negative substitution controls were obtained from Dako (Glostrup, Denmark).

\subsection{Virus and animal infections}

CSFV highly virulent Eystrup strain [30] was kindly provided by Dr A. Summerfield (Institute of Virology and Immunoprophylaxis, Mittelhäusern, Switzerland) and propagated on porcine kidney cell line PK15. Virus titre was determined as previously described [29]. Seven-week-old specific pathogen free Large White pigs of both sexes were housed in isolation units at the Section of Healthy Pig Production and Experimentation (AFSSA, Ploufragan). One group of 24 pigs was infected by the oronasal route with $10^{6} \mathrm{TCID}_{50}$ of the Eystrup strain and slaughtered in batches of 3 at 16, 72, 96 and 168 hours post-inoculation (hpi), and in batches of 6 at 24 and 48 hpi. A group of 8 pigs was similarly mock inoculated with culture supernatant of uninfected PK15 cells and slaughtered in batches of 2 at 0,48 , 96 and 168 hpi. Finally, a group of 10 control pigs was non-inoculated and slaughtered in a batch of 6 at 0 hpi and in batches of 2 at 24 and 72 hpi. Clinical signs such as anorexia, depression, fever, purple skin discoloration, diarrhoea and cough, were observed daily during the experiment and scored as previously described [30]. Accepted principles of animal care were followed and pigs were sacrificed by intravenous booster of sodium pentobarbital in compliance with the animal welfare experimentation agreement given by the Direction des Services Vétérinaires des Côtes d'Armor (AFSSA registration No. B-22-745-1, AJ and GKS authorisations No. 22-27 and 22-26, respectively).

\subsection{Sample collection and treatments}

Whole, EDTA and heparinized blood samples were taken before euthanasia. Immediately thereafter, palatine tonsils and spleens from each animal were entirely collected for laboratory investigations. Serum was obtained by centrifugation of coagulated blood at $2200 \mathrm{~g}$ for $5 \mathrm{~min}$ and stored at $-20{ }^{\circ} \mathrm{C}$ until use. EDTA blood cell counts were performed with a MS9 Coulter Counter (Beckman Coulter, Fullerton, USA). EDTA blood samples and parts of tonsils and spleens were stored at $-70{ }^{\circ} \mathrm{C}$ until viral genome detection. Other tonsil and spleen samples were quickly snap frozen in isopentane/liquid nitrogen and stored at $-70{ }^{\circ} \mathrm{C}$ until cutting of serial $5 \mu \mathrm{m}$-thick frozen sections that were fixed either on RNAse free polylysin slides in $4 \%$ paraformaldehyde for $10 \mathrm{~min}$ for subsequent in situ hybridization, or on untreated slides in $80 \%$ cold acetone for $10 \mathrm{~min}$ for immunohistochemistry (IHC). After washing, both slide types were stored at $-70^{\circ} \mathrm{C}$ until use. Finally, the remaining tissue was weighed, cut, minced in RPMI 1640 (Invitrogen) and filtered through nylon membrane $(100 \mu \mathrm{m})$. Peripheral blood mononuclear cells (PBMC) were isolated from heparinized blood using Ficoll-Hypaque (Amersham Biosciences, Piscataway, USA) density centrifugation, at $2200 \mathrm{~g}$ for $15 \mathrm{~min}$ at $18{ }^{\circ} \mathrm{C}$. After PBS washes, total tonsillar and splenic cell suspensions and PBMC were stored in fetal calf serum (Laboratoires Eurobio, Courtaboeuf, France) containing $10 \%$ DMSO (Sigma-Aldrich) at $-70{ }^{\circ} \mathrm{C}$ until flow cytometry analyses.

\subsection{Viral genome detection}

Viral RNA was extracted from tissue samples using RNeasy kit (Qiagen, Courtabœuf, France) and detected by closed-one tube RT-nested PCR. The same procedure as described by McGoldrick et al. [28] was followed except that A14 inner primer was replaced by PPC1 primer (5'-CAG GTC GTA CCC CAT CA-3') [27], giving rise to a 150 nucleotide-long CSFV specific amplification product from 5' NTR.

\subsection{FITC-labeled probe synthesis}

Primers from the Eystrup viral strain genome sequence (GenBank accession number NC002657) were used as 5'-ACCTACCTGGCCACAGACAC-3' (nucleotides 1301-1320) and 5'-GGTGACCACGTTGATGTCAG-3' (nucleotides 1534-1553), corresponding to forward and reverse primers, respectively. The primer set resulted in an amplified fragment of $252 \mathrm{bp}$ located in $\mathrm{E}^{\mathrm{rns}}$ gene. After viral RNA extraction from virus stock, RT was performed with Moloney Murine Leukaemia Virus RT (M1701, Promega, Madison, USA), followed by PCR using Taq DNA polymerase (M1865, Promega) under these conditions: $94{ }^{\circ} \mathrm{C}$ for $10 \mathrm{~min}$ followed by 30 amplification cycles (denaturing at $94{ }^{\circ} \mathrm{C}$ for $45 \mathrm{~s}$, annealing at $55{ }^{\circ} \mathrm{C}$ for $30 \mathrm{~s}$ and elongation at $72{ }^{\circ} \mathrm{C}$ for $30 \mathrm{~s}$ ) and final elongation at $72{ }^{\circ} \mathrm{C}$ for $7 \mathrm{~min}$. The DNA product was purified using Qiaquick PCR purification kit (Qiagen), labeled with FITC-dUTP using Fluorescein High Prime kit (Roche Diagnostics, Meylan, France) and stored at $-20{ }^{\circ} \mathrm{C}$ until use. 


\subsection{Fluorescence in situ hybridization}

Tissue sections fixed on polylysin slides were treated in $0.2 \mathrm{~N} \mathrm{HCl}$ at room temperature for $20 \mathrm{~min}$ and then incubated in PBS with $25 \mu \mathrm{g} / \mathrm{mL}$ of proteinase K (Roche Diagnostics) at $37{ }^{\circ} \mathrm{C}$ for $20 \mathrm{~min}$. Reaction was stopped in PBS containing $0.2 \%$ glycin, and after successive washes in PBS and $2 \times$ SSC, slides were air-dried and mounted in a Gene Frame incubation chamber of $25 \mu \mathrm{L}$ (Abgene, Epson, UK). Tissues were pre-hybridized at $42{ }^{\circ} \mathrm{C}$ for $1 \mathrm{~h}$ in hybridization buffer consisting of $2 \times$ SSC with $50 \%$ formamide, $1 \times$ Denhart solution and $100 \mu \mathrm{g} / \mathrm{mL}$ fish sperm DNA. The hybridization mix consisted of $0.66 \mathrm{ng} / \mu \mathrm{L}$ of FITC-labeled probe diluted in hybridization buffer with addition of $10 \%$ dextran sulfate and $250 \mu \mathrm{g} / \mathrm{mL}$ fish sperm DNA. This reaction mix was denatured at $95{ }^{\circ} \mathrm{C}$ for $10 \mathrm{~min}$ and applied to tissue sections under cover slides. After overnight hybridization at $42^{\circ} \mathrm{C}$, sections were successively washed in $2 \times \mathrm{SSC}$, in $1 \times$ $\mathrm{SSC}$, in $0.5 \times \mathrm{SSC}$ and in $0.1 \times \mathrm{SSC}$, each for $30 \mathrm{~min}$ at $42{ }^{\circ} \mathrm{C}$. Hoechst stain solution (Sigma-Aldrich) was added at $5 \mu \mathrm{g} / \mathrm{mL}$ on sections for $15 \mathrm{~min}$. Finally, sections were air-dried before application of coverslip over fluorescence mounting medium (Dako). For each staining assay, three sequential sections per tissue for each pig were observed using an Olympus BX41 epifluorescence microscope. Images of representative areas for each tissue were recorded on a Spot Insight FireWire CCD camera using Spot Advanced software (Diagnostic Instruments, Sterling Heights, USA).

\subsection{Fluorescence immunohistochemistry}

Non-specific binding of $\mathrm{Ab}$ to tissue sections was blocked for $1 \mathrm{~h}$ in PBS containing 3\% bovine serum albumin (BSA) and $0.1 \%$ Triton X100. Then, all incubations were done in the dark at room temperature. Sections were incubated with 1 or 2 different conjugated-mAb at $20 \mathrm{ng} / \mu \mathrm{L}$ for $1 \mathrm{~h}$ in PBS containing 1\% BSA, $0.1 \%$ Triton X100. When biotinylated-antibodies and anti-NS3 were used, sections were incubated for $1 \mathrm{~h}$ with streptavidin coupled to RPE-cyanin-5 and RPEconjugated polyclonal goat $\mathrm{F}\left(\mathrm{ab}^{\prime}\right)_{2}$ anti-mouse Ig respectively. Finally, Hoechst stain solution was added on sections and microscopy observations were performed as described above.

\subsection{Flow cytometry analyses}

After thawing, PBMC, tonsillar and splenic cell viability was evaluated by the Trypan Blue dye ex- clusion test. Each single-, double- or triple-color staining procedure was performed on $5 \times 10^{5}$ cells saturated with $0.5 \mu \mathrm{g}$ FITC or/and RPE or/and biotin labeled primary $\mathrm{mAb}$ for $30 \mathrm{~min}$ at $4{ }^{\circ} \mathrm{C}$. Cells stained with biotinylated $\mathrm{mAb}$ were incubated with streptavidin coupled to RPE-cyanin-5 for $30 \mathrm{~min}$ at $4{ }^{\circ} \mathrm{C}$ and fixed as other stained cells. After labeling of cell-surface proteins, cytokines were detected by intracellular staining using Cytofix/Cytoperm kit (BD Biosciences Pharmingen, San José, USA). Flow cytometry analyses were performed on a constant event number of 20000 cells fixed with $2 \%$ paraformaldehyde, acquired on a FACSort flow cytometer using CellQuest Sofware (both from BD Biosciences) and analyzed using WinList 5.0 (Verity Software House, Topsham, USA). Due to the strong leucopoenia and hemorrhagic disorders that resulted from the infection, low amounts of viable cells were available within PBMC, tonsil and spleen total cell suspensions, thus allowing only one repetition per immunostaining assay to be performed per pig. Each assay was repeated on 3 animals at each time point pi.

Cell subset frequencies obtained from flow cytometry analyses performed on PBMC were used to calculate absolute cell numbers per $\mathrm{mL}$ of blood, by reporting cell subset percentages to the number of leucocytes counted per $\mathrm{mL}$ of total blood reduced by the number of granulocytes.

Flow cytometry analyses on total cell suspension from the tonsil and spleen were realized on an electronic gate containing only mononuclear cells, by forwarding scatter versus side scatter (FSC/SSC) dot plot, in order to exclude granulocytes. Indeed, granulocytes are known to express CD172a as other myeloid cells such as monocytes, macrophages and DC, and to express CD11R1 as cDC [22]. CD11R1 ${ }^{+}$ CD172 $\mathrm{a}^{+}$cells corresponding to $\mathrm{cDC}$ and $\mathrm{CD} 4^{+}$ CD172 $\mathrm{a}^{+}$cells corresponding to $\mathrm{pDC}$ were detected in the mononuclear cell gate. Percentages of DC that expressed CD1a, CD80/86 or cytokine were subsequently obtained in another gate that included either CD11R1 $1^{+}$CD172a ${ }^{+}$cells or CD4 ${ }^{+}$ CD172a ${ }^{+}$cells, respectively. Since the size of lymphoid organs and their different compartments were reported to be largely dependent on factors such as breed, age and antigenic stimulation, absolute numbers of cells per gram of tissue and per whole organ should be given in any experiment dealing with alterations of the immune system [9]. However, we observed that the size and weight of the tonsil and spleen were constant between individuals at a given time point post-infection but that the 
cell amounts, obtained after isolation and freezingthawing, varied from one experiment to another (data not shown). Since flow cytometry analyses were performed on a constant event number, after immunostaining of a constant cell number, all results concerning tonsillar and splenic cell subsets were given as relative numbers.

\subsection{Detection of cytokines in serum}

IFN- $\alpha$ and IL-12 were detected by sandwich ELISA as previously described [23]. TNF- $\alpha$ and IL-10 were detected using commercial ELISA kits from Biosource, IL-6 using a kit from R\&D Systems (Minneapolis, USA), IL-18 and IFN- $\gamma$ using kits from Tebu-Bio (Le Perray-en-Yvelines, France)

\subsection{Statistical analysis}

Due to the small size of the data sets, all the statistical tests used were non-parametric. For each data set, variations in the time course postinoculation were analysed by comparing data obtained at $\mathrm{t}(\mathrm{h}=16,24,48,72,96$ or 168$)$ with data obtained at $\mathrm{t}(0)$. When presented as numbers or concentrations, data were analysed using the Mann \& Whitney test. In case of results expressed as percentages, analyses were performed on total strengths using the $\chi 2$ test. All statistical analyses were performed using Systat 9 software $^{1}$. Comparisons were performed with a limit of significance of $p<0.05$ (indicated by $*$ ) or of $p<0.01$ (indicated by $* *)$.

\section{RESULTS}

\subsection{Clinical signs and blood cell counts}

Control and mock-infected animals remained healthy with normal body temperature $\left(39.5{ }^{\circ} \mathrm{C}\right)$ and normal blood cell count values throughout the experiment (Fig. 1). Both groups were reassembled for laboratory investigations.

All CSFV-inoculated animals had high increases in body temperature from $48 \mathrm{hpi}$, reaching a mean peak of $41.1^{\circ} \mathrm{C}$ at $72 \mathrm{hpi}$ and remaining at an average of $40.3{ }^{\circ} \mathrm{C}$ until $168 \mathrm{hpi}$. Growth was affected from $24 \mathrm{hpi}$ and weight loss was observed from 96 hpi (data not shown). Clinical scores rose from 0 level

\footnotetext{
${ }^{1}$ SPSS Inc., 1998.
}

at 24 hpi to 8 level at 168 hpi. Tonsils were congested and haemorrhagic in $1 / 6$ pig killed at $48 \mathrm{hpi}, 1 / 3$ at $72 \mathrm{hpi}$, and in all animals from 96 hpi. Spleens of all infected pigs were congested and haemorrhagic from $72 \mathrm{hpi}$.

In the infected group, EDTA-blood cell counts revealed a thrombocytopenia from $24 \mathrm{hpi}$, by comparison to normal platelet values in control pigs (data not shown). They also showed a significant leucopoenia from 16 hpi (Fig. 1a), particularly due to a severe decrease in lymphocyte number (Fig. 1b). At $96 \mathrm{hpi}$, the mean lymphocyte number represented only $15 \%$ of its value in control pigs. By contrast, monocyte numbers were not significantly modified after infection (Fig. 1c) but statistical analyses revealed an obvious granulocytopenia one week pi (Fig. 1d).

\subsection{Dissemination of CSFV in blood and organs}

The presence of the CSFV genome was investigated by RT-nested PCR in blood, tonsil and spleen at different times pi (Tab. I). No CSFV RNA was detected in tissues of control and mock-inoculated animals. Viral RNA was detected in all infected pigs from 16 hpi. It was detected in one tissue out of three, the tissue identity depending on the individual. At 24 hpi, CSFV RNA was detected in blood of $4 / 6$ animals, in the tonsils of $6 / 6$ animals and in the spleen of $3 / 6$ animals. At $48 \mathrm{hpi}$, all the tissues of infected pigs contained viral genome.

Fluorescence in situ hybridization analyses revealed that the CSFV genome was located in the tonsil crypt epithelium (CE) at $24 \mathrm{hpi}$ and then in interfollicular areas (IFA) at $48 \mathrm{hpi}$ (Fig. 2a). Detection of the non-structural protein NS3 by IHC confirmed the virus location in CE and IFA at 24 hpi and its multiplication in IFA, around the crypts, at 48 hpi (Fig. 2b).

NS3 was also detected in periarteriolar lymphoid sheaths (PALS) of the spleen, as soon as $24 \mathrm{hpi}$ for some pigs or at $48 \mathrm{~h}$ in other cases (data not shown). When already detected at $24 \mathrm{hpi}$, the labeling intensity increased at 48 hpi (data not shown). CSFV RNA and NS3 protein were not detected neither in follicular germinal centres, nor in organs from control pigs. 
(a)

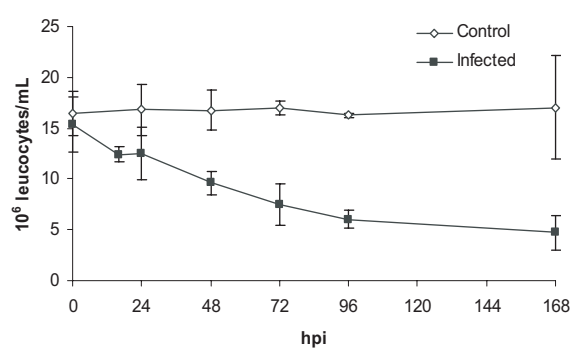

(c)

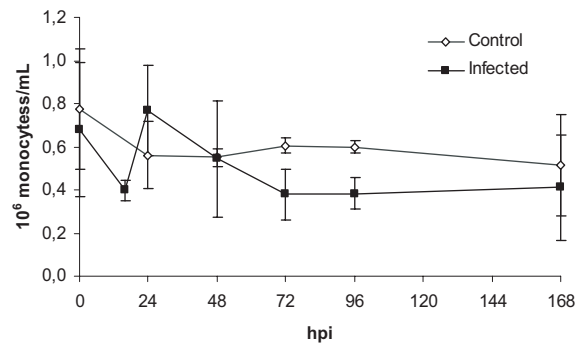

(b)

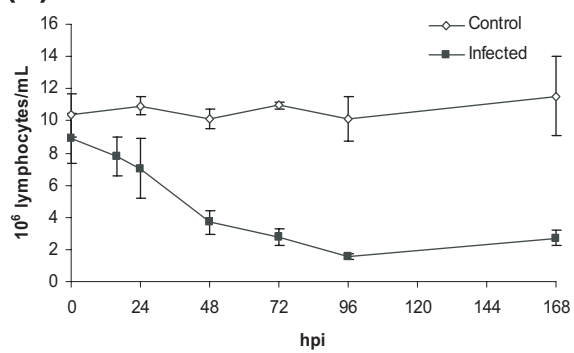

(d)

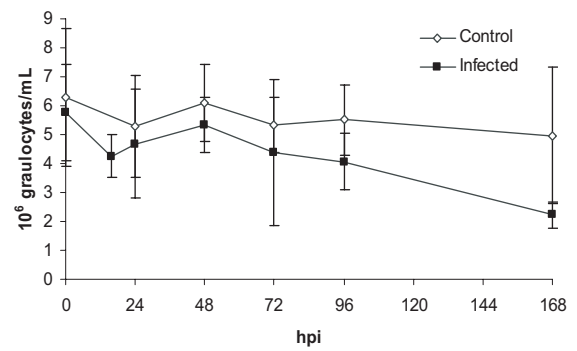

Figure 1. Numbers of white cells per $\mathrm{mL}$ of peripheral blood in the time course post-infection (hpi). (a) Leucocytes. (b) Lymphocytes. (c) Monocytes. (d) Granulocytes. The results are presented as mean \pm SD of samples from 14 (Control group) and 23 animals (Infected group) at 0 hpi, and then from 6 animals at 24 and 48 hpi and from 3 animals at other time points pi.

Table I. Detection of CSFV RNA in control, mock-inoculated and infected pigs in the time course postinoculation (hpi). The presence of virus genome was assessed by RT-PCR in blood (B), tonsil (T) and spleen (S). Results are expressed as negative (-) and positive (+) samples. $n=$ number of analysed pigs.

\begin{tabular}{|c|c|c|c|c|c|c|c|c|c|c|c|c|c|c|c|c|c|c|c|c|c|c|c|}
\hline \multirow{2}{*}{ Animals } & & \multicolumn{2}{|l|}{ hpi } & \multicolumn{2}{|l|}{0} & \multicolumn{3}{|c|}{16} & \multicolumn{3}{|c|}{24} & \multicolumn{3}{|c|}{48} & \multicolumn{3}{|c|}{72} & \multicolumn{3}{|c|}{96} & \multicolumn{3}{|c|}{168} \\
\hline & & Tissues & B & $\mathrm{T}$ & $\mathrm{S}$ & $\mathrm{B}$ & $\mathrm{T}$ & $\mathrm{S}$ & $\mathrm{B}$ & $\mathrm{T}$ & $\mathrm{S}$ & B & $\mathrm{T}$ & $\mathrm{S}$ & B & $\mathrm{T}$ & $\mathrm{S}$ & $\mathrm{B}$ & $\mathrm{T}$ & $\mathrm{S}$ & B & $\mathrm{T}$ & $\mathrm{S}$ \\
\hline Control & $n=10$ & & - & - & - & & & & - & - & - & & & & - & - & - & & & & & & \\
\hline Mock-inoculated & $n=8$ & & - & & & & & & & & & - & - & - & & & & - & - & - & - & - & - \\
\hline Infected No. 1 & $n=1$ & & - & & & + & - & - & & & & & & & & & & & & & & & \\
\hline Infected No. 2 & $n=1$ & & - & & & - & + & - & & & & & & & & & & & & & & & \\
\hline Infected No. 3 & $n=1$ & & - & & & - & - & + & & & & & & & & & & & & & & & \\
\hline Infected No. 4 & $n=1$ & & - & & & & & & + & + & + & & & & & & & & & & & & \\
\hline Infected No. 5 & $n=1$ & & - & & & & & & - & + & + & & & & & & & & & & & & \\
\hline Infected No. 6 & $n=1$ & & - & & & & & & + & + & + & & & & & & & & & & & & \\
\hline Infected No. 7 & $n=1$ & & - & & & & & & + & + & - & & & & & & & & & & & & \\
\hline Infected No. 8 & $n=1$ & & - & & & & & & + & + & - & & & & & & & & & & & & \\
\hline Infected No. 9 & $n=1$ & & - & & & & & & - & + & - & & & & & & & & & & & & \\
\hline Infected No. 10-15 & $n=6$ & & - & & & & & & & & & + & + & + & & & & & & & & & \\
\hline Infected No. 16-18 & $n=3$ & & - & & & & & & & & & & & & + & + & + & & & & & & \\
\hline Infected No. 19-21 & $n=3$ & & - & & & & & & & & & & & & & & & + & + & + & & & \\
\hline Infected No. 22-24 & $n=3$ & & - & & & & & & & & & & & & & & & & & & + & + & + \\
\hline
\end{tabular}




\subsection{Location of viral $\mathrm{E} 2$ antigen with respect to APC in secondary lymphoid organs}

Intending to analyse interactions between CSFV and DC in secondary lymphoid organs, we investigated the location of the viral envelop glycoprotein $\mathrm{E} 2$, the most immunogenic viral protein, together with APC in the tonsil and spleen. Double fluorescence IHC analyses first focused on E2 location with respect to myeloid CD172 $\mathrm{a}^{+}$cells, i.e. monocytes, macrophages or DC. E2 protein was not detected in tonsil from non-infected pigs (Fig. 3). Anti-E2/anti-CD172a double staining assays revealed numerous double positive cells in IFA as early as $24 \mathrm{hpi}$, demonstrating that most of E2 were located within myeloid cells despite some green fluorescence spots due to the presence of viral particles taken up by nonmyeloid cells (Fig. 3a). Interestingly, only rare $\mathrm{CD}_{172 \mathrm{a}^{+}} \mathrm{E}^{+}$cells were still detected in IFA at $48 \mathrm{hpi}$, while the number of CD172 $\mathrm{a}^{+}$cells seemed to increase in that area. Surprisingly, at that time point, quite all E2 proteins were transiently located into follicle centres. At $72 \mathrm{hpi}$, $\mathrm{CD}_{172 \mathrm{a}^{+}} \mathrm{E}^{+}{ }^{+}$cells were observed again in IFA, around CE, where E2 free of CD172a $\mathrm{a}^{+}$ cells was strongly detected.

IHC analyses also investigated E2 location with respect to IFN- $\alpha^{+}$cells, i.e. pDC. Rare IFN- $\alpha$ positive cells were detected in IFA of tonsil in non infected pigs (Fig. 3b). Their number markedly increased in IFA from $24 \mathrm{hpi}$ and several IFN- $\alpha^{+} \mathrm{E}^{+}$cells were easily detected. At $48 \mathrm{hpi}$, only few IFN- $\alpha^{+} \mathrm{E} 2^{+}$cells were observed in $\mathrm{T}$ cell areas, at the periphery of follicles. E2 was mostly condensed in germinal centres as already observed above from IHC analyses with anti-CD172a. At $72 \mathrm{hpi}$, the number of IFN- $\alpha^{+} \mathrm{E} 2^{+}$cells increased again. Double positive cells were detected around and in $\mathrm{CE}$, together with E2 antigen located in non IFN- $\alpha$ secreting cells.

Intrigued by the transient translocation of E2 in germinal centres at $48 \mathrm{hpi}$, we analysed sections after anti-CD21/E2 double staining (Fig. 3c). CD $21^{+}$cells include B cells and constitute primary follicles of tonsil from noninfected pigs [23]. At 24 hpi, E2 was clearly observed in IFA and the $\mathrm{CD} 21^{+}$cells did not present the viral antigen. At 48 hpi, E2 was stained in germinal centres where some $\mathrm{CD} 21^{+} \mathrm{E} 2^{+}$cells were also noticed. Rare double positive cells were still found in follicles at $72 \mathrm{hpi}$, most of them being located in IFA, between follicles and CE, while CD $21^{+}$cell-free E2 already reached CE.

IHC analyses of E2 location in the spleen gave equivalent results to studies of tonsil sections (data not shown). In spleens that were invaded by the virus very early post-inoculation, a large number of IFN- $\alpha^{+}$cells contained E2 protein at 24 hpi. This was revealed by the presence of double positive E2/IFN- $\alpha$ cells in IFA. No E $2^{+}$IFN- $\alpha^{+}$cell was detected at 48 hpi in these areas, whereas double positive cells were visualized again in PALS at $72 \mathrm{hpi}$, surrounding other $\mathrm{E} 2^{+}$. IFN- $\alpha^{-}$cells were located close to blood vessels.

\subsection{Variations in $\mathrm{DC}$ frequencies}

In order to further analyse the effect of CSFV on DC subsets, we investigated the variations in $\mathrm{cDC}$ and $\mathrm{pDC}$ frequencies in organs and blood.

IHC assays aimed to detect $\mathrm{CD} 4{ }^{+} \mathrm{IFN}-\alpha^{+}$ cells in tonsil (Fig. 4a) and spleen (Fig. 4b), revealed an increase in the $\mathrm{pDC}$ number in T cell areas after infection. Double labeling assays with anti-CD172a together with anti-IFN- $\alpha$ or anti-CD4 antibodies provided similar pictures (data not shown).

DC frequencies were also analysed in blood, tonsil, and spleen in the time course pi, by flow cytometry analyses. Around $0.3 \times$ $10^{6} \mathrm{CD} 11 \mathrm{R} 1^{+} \mathrm{CD} 172 \mathrm{a}^{+} \mathrm{cDC}$ and $0.25 \times 10^{6}$ $\mathrm{CD} 4{ }^{+} \mathrm{CD} 172 \mathrm{a}^{+}$pDC were measured in mean per $\mathrm{mL}$ of blood in control pigs (Fig. 5a). After CSFV infection, the cDC number immediately decreased markedly in blood, reaching at 48 and 96 hpi frequencies significantly different from frequencies at 0 hpi. By contrast, the number of $\mathrm{pDC}$ was not found significantly different. In tonsil, CD172 $\mathrm{a}^{+} \mathrm{CD} 11 \mathrm{R} 1^{+}$ $\mathrm{cDC}$ and $\mathrm{CD} 172 \mathrm{a}^{+} \mathrm{CD} 4^{+} \mathrm{pDC}$ frequencies slightly decreased at 24 and $16 \mathrm{hpi}$, respectively, but these modifications were punctual and the frequencies remained globally constant, representing $0.7 \%$ and $0.9 \%$ of total cell suspension, respectively (Fig. 5b). In the spleen, both CD11R $1{ }^{+} \mathrm{CD} 172 \mathrm{a}^{+} \mathrm{cDC}$ and 
(a)

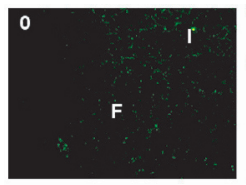

(b)

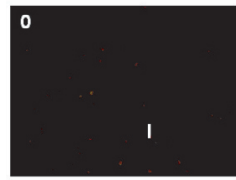

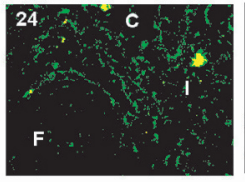

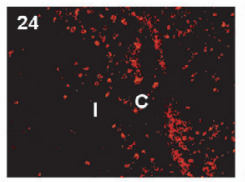

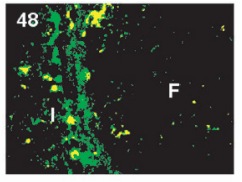

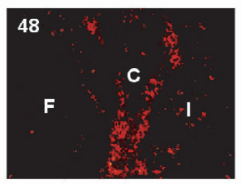

Figure 2. Location of CSFV in the tonsil in the time course post-infection. (a) CSFV RNA detection by green fluorescence in situ hybridization; magnification $\times 630$. (b) NS3 protein detection by red fluorescence IHC; magnification $\times 200$. Numbers correspond to hpi; C, crypt; F, follicle; I, interfollicular area. At each time point, a representative section out of three per one animal out of three is shown.

(a)

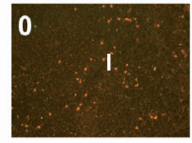

(b)

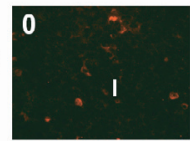

(c)

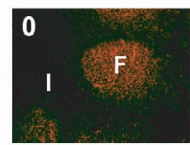

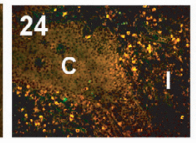
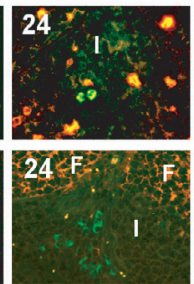
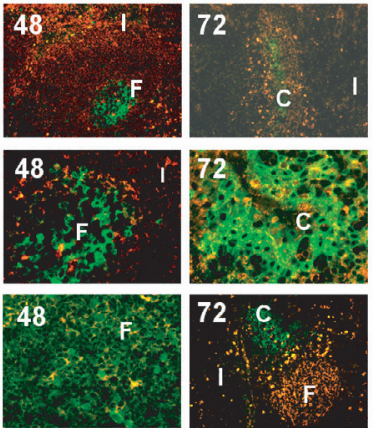
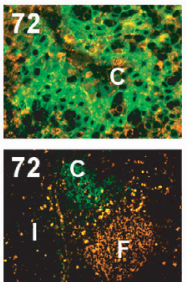

Figure 3. Co-location of E2 viral antigen and APC in tonsil in the time course after CSFV infection. (a) Anti-E2 (green) and anti-CD172a (red) double staining identifying E2 ${ }^{+} \mathrm{CD} 172 \mathrm{a}^{+}$cells (yellow); magnification $\times 200$. (b) Anti-E2 (green) and anti-IFN- $\alpha$ (red) double staining identifying E2 $2^{+}$IFN- $\alpha^{+}$cells (yellow); magnification $\times 630$. (c) Anti-E2 (green) and anti-CD21 (red) double staining identifying E2 ${ }^{+} \mathrm{CD} 21^{+}$cells (yellow); magnification $\times 200$ at 0 and 72 hpi and $\times 630$ at 24 and 48 hpi. Numbers correspond to hpi; C, crypt; F, follicle; I, interfollicular area. At each time point, a representative section out of three per one animal out of three is shown.

(a)

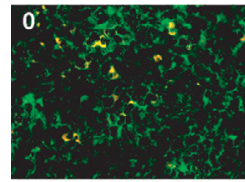

(b)

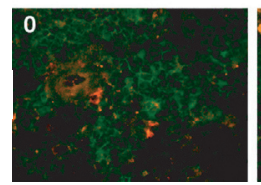

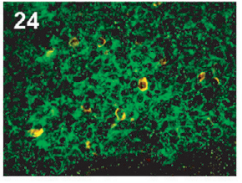

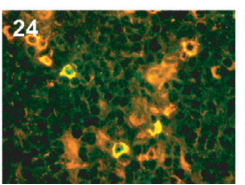

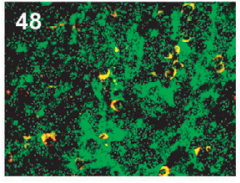

48

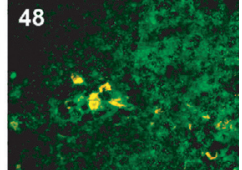

Figure 4. Location of IFN- $\alpha$ expressing cells in secondary lymphoid organs after CSFV infection. AntiCD4 (green) and anti-IFN- $\alpha$ (red) double staining identifying CD4 $4^{+}$IFN- $\alpha^{+}$pDC (yellow) in T cell areas of (a) tonsil and (b) spleen. Magnification $\times 630$. Numbers correspond to hpi. At each time point, a representative section out of three per one animal out of three is shown. 
(a)

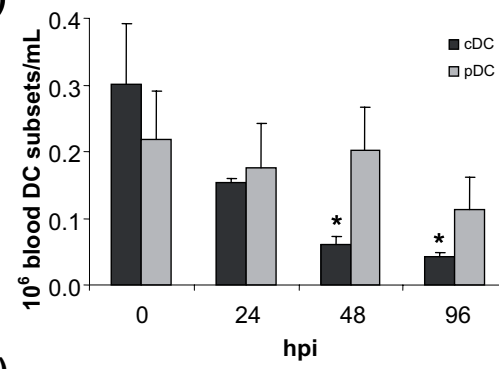

(b)

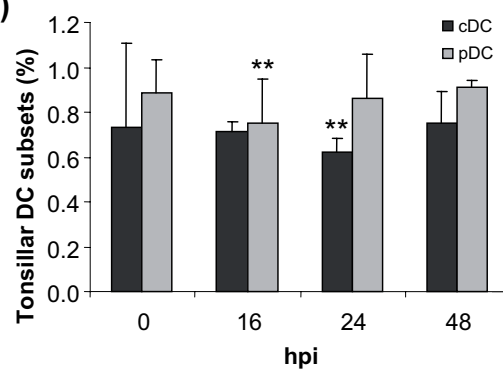

(c)

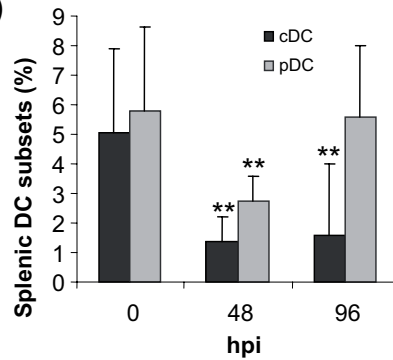

Figure 5. Variations in $\mathrm{CD} 11 \mathrm{R} 1{ }^{+} \mathrm{CD} 172 \mathrm{a}^{+} \mathrm{cDC}$ and $\mathrm{CD} 4{ }^{+} \mathrm{CD} 172 \mathrm{a}^{+}$pDC numbers after CSFV infection. (a) DC numbers per $\mathrm{mL}$ of blood. (b) DC percentages within total cell suspensions from the tonsil. (c) DC percentages within total cell suspensions from the spleen. Results are presented as mean \pm SD of samples from 6 to 9 animals at 0 hpi and from 2 to 3 individuals at various times pi. $* p<0.05$ compared with corresponding values at 0 hpi using Mann \& Withney test. ** $p<0.01$ compared with corresponding values at 0 hpi using $\chi^{2}$ test.

$\mathrm{CD} 4{ }^{+} \mathrm{CD} 172 \mathrm{a}^{+} \mathrm{pDC}$ subsets, that represented each one around 5-6\% of total splenic cell suspension in non infected pigs, markedly decreased post-infection. Thus, cDC only represented $1.6 \%$ at $96 \mathrm{hpi}$. pDC were reduced to $2.7 \%$ at 48 hpi but increased again to their normal value at 96 hpi (Fig. 5c). (a)

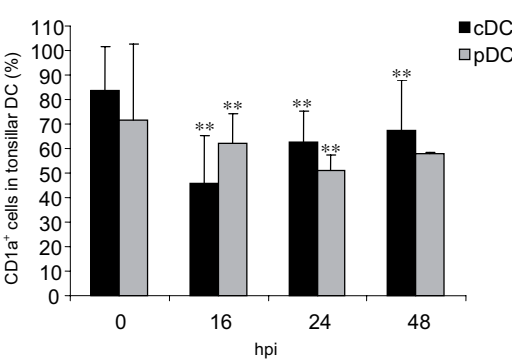

(b)

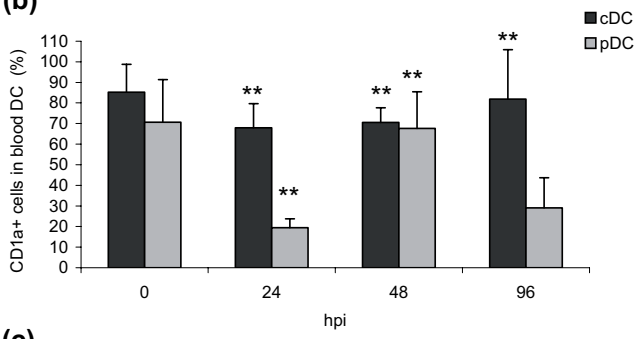

(c)

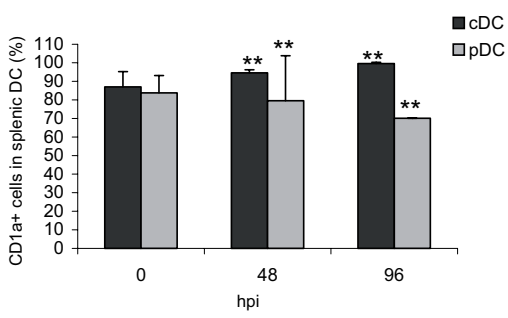

Figure 6. Variation in CD1a expression by DC subsets after CSFV infection. Percentages of $\mathrm{CD} \mathrm{a}^{+}$cells within CD11R $1{ }^{+} \mathrm{CD} 172 \mathrm{a}^{+} \mathrm{cDC}$ and $\mathrm{CD} 4{ }^{+} \mathrm{CD} 172 \mathrm{a}^{+}$pDC in (a) tonsil, (b) PBMC and (c) spleen were measured by triple-color flow cytometry. Results are presented as mean \pm SD from analyses conducted on samples from 6 to 9 individual animals at 0 hpi and 2 to 3 animals per time point pi. $* * p<0.01$ compared with corresponding values at 0 hpi using the $\chi 2$ test.

\subsection{Maturation status of DC subsets}

To evaluate the maturation status of DC subsets after CSFV infection, we intended to measure the expression of CD1a, implicated in lipid antigen binding, as well as the expression of CD80/86, a co-stimulation molecule, by CD172 $\mathrm{a}^{+} \mathrm{CD} 11 \mathrm{R} 1^{+} \mathrm{cDC}$ and CD172a $\mathrm{a}^{+} \mathrm{CD} 4^{+}$ pDC from the three studied cell suspensions, using a three-color flow cytometry analyses. 
In the tonsils of control pigs, most of DC, i.e. around $80 \%$ of $\mathrm{cDC}$ and $70 \%$ of pDC, expressed CD1a (Fig. 6a). After infection, less than $50 \%$ of cDC were still CD1a $\mathrm{C}^{+}$as early as 16 hpi. Then, cDC expressed again CD1a at 48 hpi without reaching a normal level. These decreases were found significant as compared to the CD1a expression level before infection. Similarly to cDC but to a lesser extent, CD1 ${ }^{+}$ $\mathrm{pDC}$ frequency decreased after challenge, with around $60 \%$ of pDC expressing this marker at 24 hpi. Within PBMC, 85\% of cDC expressed $\mathrm{CD} 1 \mathrm{a}$ at 0 hpi. After infection, this percentage decreased and was maintained at $70 \%$ between 24 and 48 hpi. It raised back up to the initial value at 96 hpi (Fig. 6b). In pDC, CD1a appeared to be expressed with a particular kinetic during the first days of infection. Indeed, this marker was detected in $70 \%$ of pDC at 0 hpi, whereas only $20 \%$ of these cells were positive at $24 \mathrm{hpi}$. At $48 \mathrm{hpi}$, CD1a expression concerned again $70 \%$ of pDC but was limited to $40 \%$ of the subset at 96 hpi. In spleen, around $90 \%$ of cDC expressed CD1a at 0 hpi, as in blood. Conversely to the phenomenon observed in blood, CD1a expression increased from 48 hpi and concerned about $100 \%$ of the subset at 96 hpi (Fig. 6c). By contrast, CD1a expression by pDC was significantly reduced from $85 \%$ to $70 \%$ between 0 and 48 hpi.

Interestingly, CD80/86 appeared to be expressed by DC with an opposite kinetic to CD1a. In blood, co-stimulation molecule expression increased both in $\mathrm{cDC}$ and $\mathrm{pDC}$ between 0 and 24 hpi (Fig. 7a). Thus, the frequency of $\mathrm{CD} 80 / 86^{+} \mathrm{cDC}$ varied on average from $7 \%$ to $24 \%$ and $\mathrm{CD} 80 / 86^{+}$pDC from 9 to $14 \%$. Then, a strong decrease in CD80/86 expression was observed. At 48 hpi it only concerned $2 \%$ and $4 \%$ of $\mathrm{cDC}$ and $\mathrm{pDC}$, respectively. This lack of expression was slightly reversed in pDC at 96 hpi. In spleen, CD80/86 was expressed by only an average of $5 \%$ of both DC subsets at 0 hpi but increased postinfection up to $20 \%$ of pDC at 96 hpi (Fig. 7b). Because of low numbers of viable cells within tonsil cell suspensions, CD80/86 expression by DC could not be investigated in this tissue. (a)

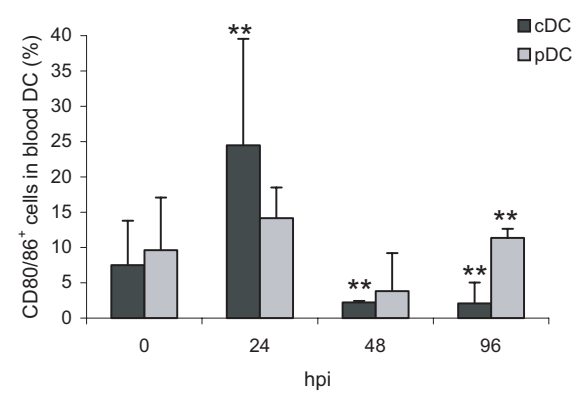

(b)

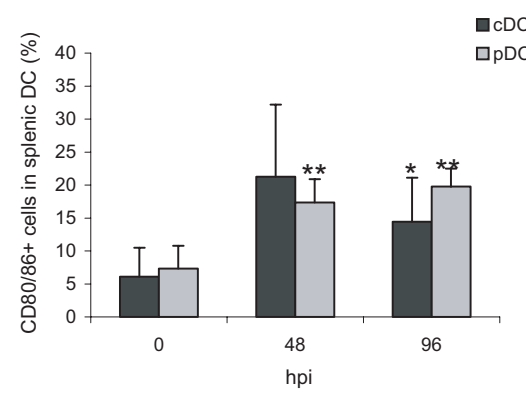

Figure 7. Variation in CD80/86 expression by DC subsets after CSFV infection. Percentages of CD80/86 ${ }^{+}$cells within CD11R $1^{+} \mathrm{CD} 172 \mathrm{a}^{+} \mathrm{cDC}$ and $\mathrm{CD} 4{ }^{+} \mathrm{CD}_{172 \mathrm{a}^{+}} \mathrm{pDC}$ in (a) PBMC and (b) spleen were measured by triple-color flow cytometry. Results are presented as mean \pm SD from analyses conducted on samples from 6 to 9 individual animals at 0 hpi and 2 to 3 animals per time point pi. $* * p<0.01$ compared with corresponding values at 0 hpi using $\chi 2$ test.

\subsection{Cytokine expression by DC subsets}

In order to evaluate DC activation status after CSFV infection, we measured cytokine expression by $\mathrm{CD} 172 \mathrm{a}^{+} \mathrm{CD} 11 \mathrm{R} 1^{+} \mathrm{cDC}$ and $\mathrm{CD} 172 \mathrm{a}^{+} \mathrm{CD} 4^{+} \mathrm{pDC}$ in the tonsil, blood and spleen in the time course pi.

Three-color flow cytometry analyses conducted on tonsil cell suspensions showed that numbers of TNF- $\alpha$ and IFN- $\alpha$ positive cells significantly increased in both DC subsets in the time course post-infection, but with different kinetics and frequencies (Fig. 8). Thus, $18 \%$ of $\mathrm{cDC}$ expressed TNF- $\alpha$ in the tonsils of control pigs, whereas only $8.5 \%$ of pDC expressed this cytokine (Fig. 8a). After infection, TNF- $\alpha^{+}$cDC frequency immediately raised up, reaching $70 \%$ at 48 hpi. pDC were also 
(a)

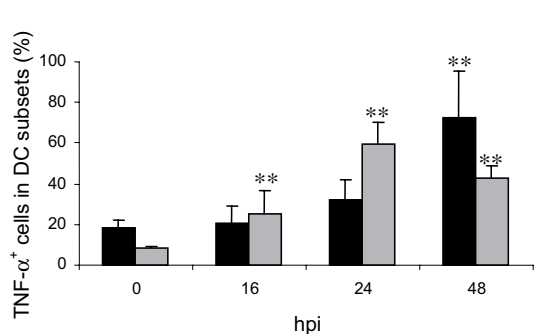

(b)

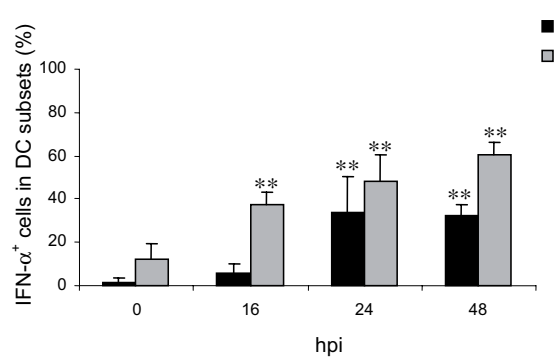

Figure 8. Activation status of DC subsets in tonsil after CSFV infection. Percentages of (a) $\mathrm{TNF}-\alpha^{+}$cells and (b) IFN- $\alpha^{+}$cells within CD $11 \mathrm{R} 1{ }^{+} \mathrm{CD} 172 \mathrm{a}^{+} \mathrm{cDC}$ and CD ${ }^{+} \mathrm{CD} 172 \mathrm{a}^{+} \mathrm{pDC}$, measured by triple-color flow cytometry. Results are presented as mean \pm SD from analyses conducted on samples from 6 to 9 individual animals at 0 hpi and 2 to 3 animals per time point pi. $* * p<0.01$ compared with corresponding values at 0 hpi using $\chi 2$ test.

activated to express TNF- $\alpha$ after challenge. TNF- $\alpha^{+}$pDC represented $60 \%$ of the subset at 24 hpi but decreased to $42 \%$ at 48 hpi. $12 \%$ of pDC expressed a basal level of IFN- $\alpha$ in the steady state, whereas very few cDC expressed this cytokine (Fig. 8b). After infection, cDC were activated with respect to IFN- $\alpha$ expression, as $5 \%$ of them were IFN- $\alpha$ positive at 16 hpi and $32 \%$ at 24 hpi. A more important effect was observed in pDC which rapidly enhanced their IFN- $\alpha$ expression after challenge. Thus, around $60 \%$ of them were found IFN- $\alpha^{+}$ at $48 \mathrm{hpi}$. Regarding the low number of viable cells obtained from tonsils to perform flow cytometry analyses, no other cytokine expression in DC subsets was investigated in this tissue.

Analyses performed on PBMC showed that $10-20 \%$ of both CD $172 \mathrm{a}^{+} \mathrm{CD} 11 \mathrm{R} 1^{+} \mathrm{cDC}$ and CD $172 \mathrm{a}^{+} \mathrm{CD}^{+}{ }^{+}$pDC expressed TNF- $\alpha, \mathrm{IL}-12$ and IL-10 in blood at 0 hpi (Figs. 9a-9b). In non-infected pigs, IFN- $\alpha$ was also expressed by $15 \%$ of pDC, but less than $2 \%$ of cDC. After infection, around $20-25 \%$ of $\mathrm{cDC}$ and $70 \%$ of $\mathrm{pDC}$ were detected as TNF- $\alpha^{+}$and IL-12+ cells at 24 hpi. Expression of IL-10 by cDC slightly decreased pi, while IL-10 expression was up-regulated in pDC early pi. Expression of IFN- $\alpha$ was stimulated in pDC and in $\mathrm{CDC}$ up to $48 \mathrm{hpi}$, before being reduced.

As observed in blood, 5-10\% of cDC from spleen expressed basal levels of TNF- $\alpha$, IL12 , IL-10 but no IFN- $\alpha$ at the steady-state (Fig. 9c). Less than $5 \%$ of splenic pDC expressed these cytokines before inoculation (Fig. 9d). After infection, cDC expressed TNF- $\alpha$ and IL-10 in an amount of $65 \%$ and $85 \%$, respectively. IL-12 expression by cDC also increased in the time course post-infection but to a lower extent, and $15 \%$ of $\mathrm{cDC}$ were able to secrete IFN- $\alpha$ (Fig. 9c). Expression of these four cytokines by splenic pDC also significantly increased after infection (Fig. 9d), although numbers of cytokine expressing $\mathrm{pDC}$ were lower than cDC except for IFN- $\alpha$.

\subsection{Release of cytokines in serum after infection}

Since expression of IFN- $\alpha$, TNF- $\alpha$, IL12 , IL-10 was stimulated in DC early postinfection, we measured their productions in serum in the time course pi. IFN- $\alpha$ level increased as early as $16 \mathrm{hpi}$, reaching a mean peak of $33800 \mathrm{IU} / \mathrm{mL}$ at 96 hpi, i.e. 200 times more than in serum of non infected animals (Fig. 10a). Similarly, TNF- $\alpha$ level increased in the first hpi and reached a maximum of $320 \mathrm{pg} / \mathrm{mL}$ at $96 \mathrm{hpi}$, i.e. 8 times more than the basal level, before decreasing (Fig. 10b). On the contrary, IL-12 secretion did not significantly vary during the first week pi, remaining quite constant at $30-40 \mathrm{ng} / \mathrm{mL}$ (Fig. 10c). For IL-10, two peaks of release were observed, the first one at $24 \mathrm{hpi}$, and the second one, more important, 6 days later, i.e. 1-week pi (Fig. 10d). IL-6 was transiently detected at 96 hpi in 2/3 infected animals, with levels around 200 pg/mL (Fig. 10e). Finally, IFN- $\gamma$ and more rarely IL-18, were also transiently detected at 72 hpi in some animals (Figs. 10f and $10 \mathrm{~g}$ ). 
(a)
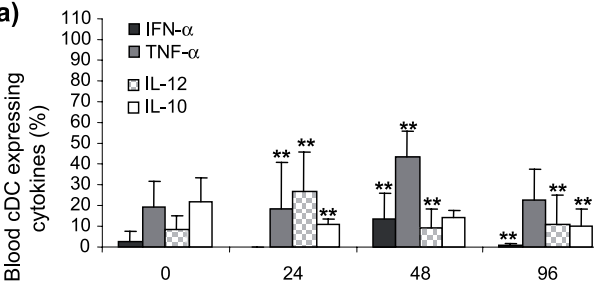

hpi

(c)

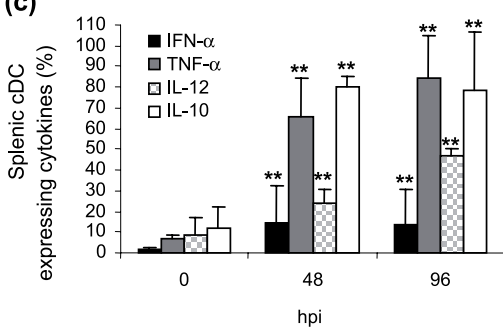

(b) 110

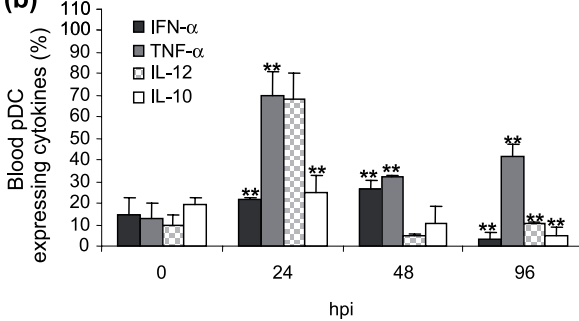

(d)

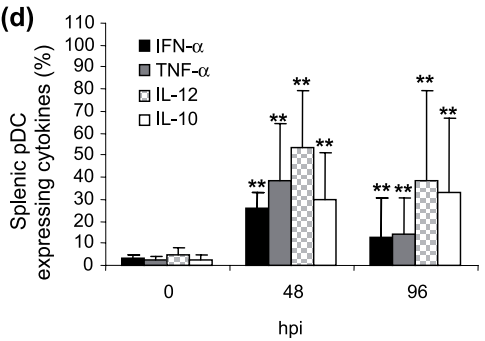

Figure 9. Expression of IFN- $\alpha$, TNF- $\alpha$, IL-12 and IL-10 by CD11R $1^{+}$CD $172 \mathrm{a}^{+}$cDC and CD $4{ }^{+} \mathrm{CD} 172 \mathrm{a}^{+}$ pDC. Percentages of cDC (a) and pDC (b) that express cytokines in blood. Percentages of cDC (c) and pDC (d) that express cytokines in spleen. Results from triple-color flow cytometry analyses are presented as mean \pm SD from experiments conducted on samples from 6 to 9 individual animals at 0 hpi and 2 to 3 animals per time point pi. ${ }^{* *} p<0.01$ compared with corresponding values at 0 hpi using $\chi 2$ test.

\section{DISCUSSION}

In this study, we first described the activation of $\mathrm{cDC}$ and $\mathrm{pDC}$ in secondary lymphoid organs and blood in the early time course after CSFV inoculation, together with viral components dissemination and cytokine production in serum.

Clinical signs and lesions observed in infected pigs were in accordance with previous data describing the Eystrup strain as a highly virulent CSFV strain [26, 30]. As revealed by viral RNA and NS3 protein detections, CSFV first invaded the tonsil, its entry site, and rapidly disseminated in the blood system, reaching the spleen between 24 and 48 hpi. In the tonsil, the virus was detected in crypts at $24 \mathrm{hpi}$, in accordance with previous reports describing mucosal epithelial cells as virus target cells [25]. At that time, numerous particles had already reached the IFA where they immediately multiplied. At $72 \mathrm{hpi}$, an increasing amount of viral particles was located in the crypt epithelium, supporting virus dissemination. CSFV also actively replicated in
PALS from spleen early post-infection, confirming hypotheses drawn by others [38]. The viral genome was never detected in tonsil and spleen germinal centers, unlike observations made in porcine lymph nodes [44]. These differences were in agreement with the fact that follicles constitute the virus entry site in lymph nodes, due to the inverted structure of these organs in the pig.

Looking for viral antigen uptake by APC in the tonsil and spleen, we showed that CSFV E2 protein was located in $\mathrm{T}$ cell areas within $\mathrm{CD} 172 \mathrm{a}^{+}$myeloid cells and IFN- $\alpha^{+}$ cells. Cells expressing CD172a antigen and/or IFN- $\alpha$ included two DC subsets we previously characterized in swine secondary lymphoid organs [23]. Further investigations would be necessary to ascertain that the viral immunogenic protein was processed in $\mathrm{cDC}$ and $\mathrm{pDC}$, and/or to know if CSFV replicated in these cells. Uptake of viral antigen by APC is also supported by the recruitment of CD172 $\mathrm{a}^{+}$and IFN- $\alpha^{+}$cells in both tonsil and spleen $\mathrm{T}$ cell areas and by the intriguing disappearance of 
(a)

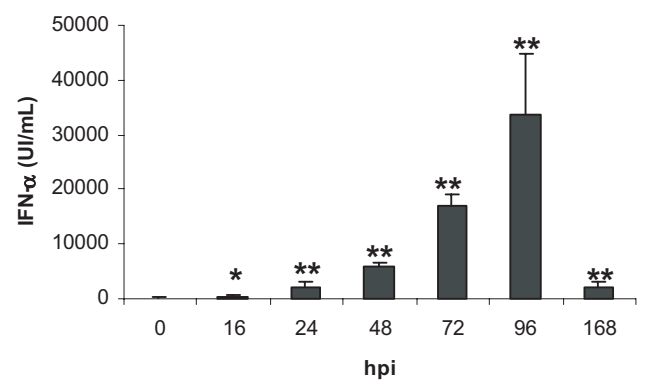

(c)

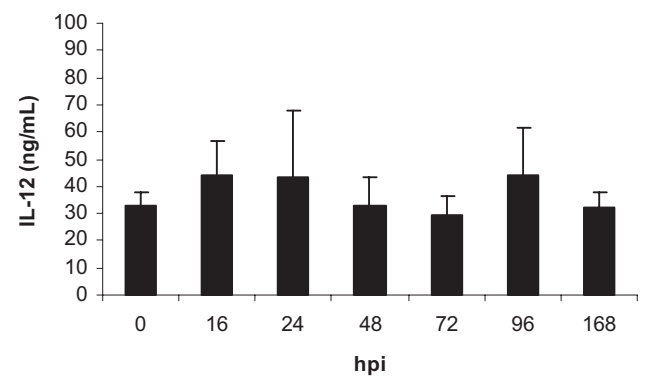

(e)

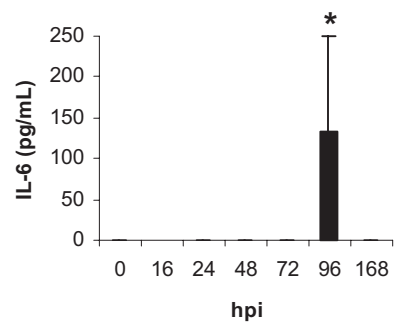

(b)

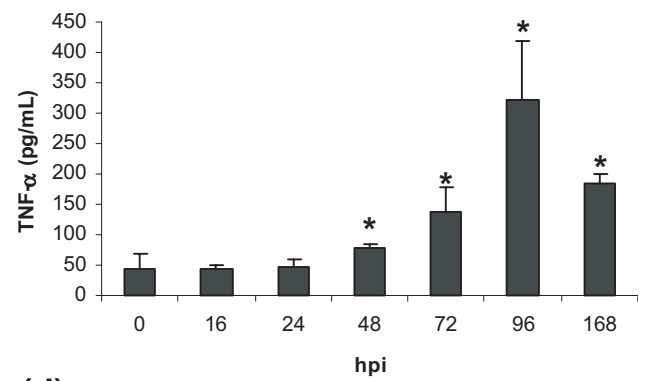

(d)

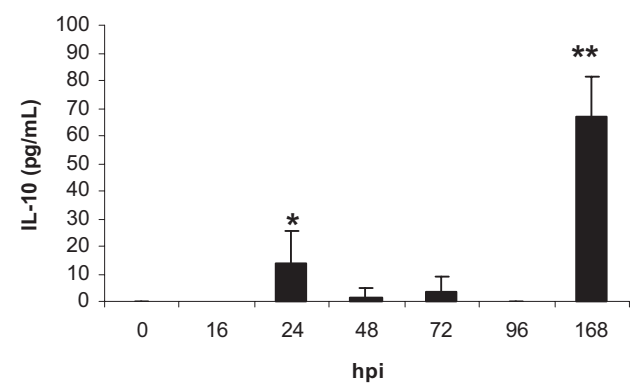

(g) (f)

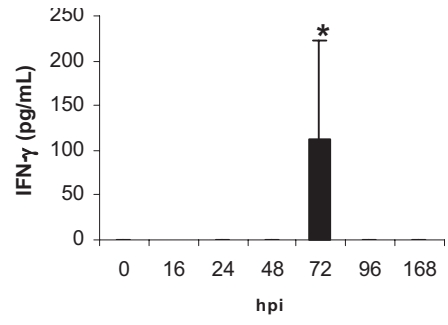

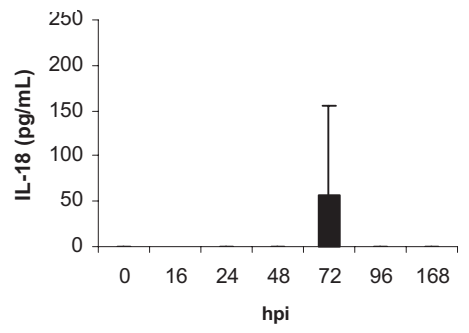

Figure 10. Cytokine levels in serum in the time course post-infection. (a) IFN- $\alpha$, (b) TNF- $\alpha$, (c) IL-12, (d) IL-10, (e) IL-6, (f) IFN- $\gamma$ and (g) IL-18. Results are presented as mean \pm SD of samples from 6 to 7 individual animals at 0 hpi and from 3 individual animals at other hpi. $* p<0.05$ and ${ }^{* *} p<0.01$ compared with values at 0 hpi using Mann \& Whitney test.

E2 from these areas at 48 hpi. Investigations on tonsil sections clearly showed the transient location of the viral antigen into follicles at that time point. Such a translocation of the viral immunogenic protein, but not of viral particles, into germinal centers could indicate that the virus was captured and degraded by APC, then transported by complement components from T-cell areas to follicles. Double labeling with anti-E2 and anti-CD21 antibodies revealed only sparse $\mathrm{CD} 21^{+} \mathrm{E} 2^{+}$cells into follicles at $48 \mathrm{hpi}$, and confirmed that E2 was not located at the follicle periphery but in the germinal center, within cells that were not B lymphocytes. Further investigations would be necessary to identify the cells that loaded E2, which could be follicular DC. Indeed, follicular DC are stromal cells located in germinal centers that present Ag-Ab complexes to $\mathrm{B}$ cells through $\mathrm{Fc}$ receptor or complement receptors such as CD21 [33]. Such a mechanism is supported by the fact that numerous 
$\mathrm{CD} 21^{+} \mathrm{E} 2{ }^{+}$cells, i.e. antigen-activated B cells, migrated to IFA at 72 hpi. It is also in accordance with a recent report that revealed co-localization of B cells and $\operatorname{IgM}$ in spleen early after CSFV infection [39], supporting the demonstration of humoral immune response induction. Altogether, these data complete previous reports about $\mathrm{E} 2$ antigen processing by APC such as macrophages and B cells in the spleen $[19,38,39]$.

Intending to know more about DC subset frequencies, maturation and activation status in CSFV infected pig, further analyses were performed on cell tissue suspensions. It appeared that $\mathrm{cDC}$ and $\mathrm{pDC}$ frequencies slightly and transiently decreased in tonsil between 16 and 24 hpi, while the cDC number markedly diminished in blood and spleen in the time course pi. We did not find any significant variation in blood pDC number, despite a jagged curve, but a strong transient decrease in spleen at $48 \mathrm{hpi}$. Altogether, these results revealed a rapid turn-over of $\mathrm{pDC}$ in the spleen, implying a migration of stimulated NIPC between blood and spleen, as previously demonstrated in mice [1] and hypothesized in pigs [43]. These data also showed that $\mathrm{cDC}$, unlike $\mathrm{pDC}$, disappeared permanently from blood after infection, preventing an efficient turn-over of these DC subset in the spleen. This observation was in agreement with in vitro studies showing that mo-DC functionalities were more affected than NIPC by CSFV infection $[4,13]$.

DC maturation after viral stimulation, demonstrated by down-regulation of CD1a expression and up-regulation of CD80/86 expression [12, 15, 31], was observed in both DC types. Less cDC expressed CD1a in tonsil and blood early after inoculation, and cDC maturation was clearly evidenced in blood through CD80/86 up-regulation. pDC matured in all tissues, with clear opposite CD1a and CD80/86 expression kinetics that also reflected, with two-stage variations, the turnover we described above about pDC circulation between blood and spleen.

$\mathrm{cDC}$ and $\mathrm{pDC}$ activation was demonstrated through cytokine expression. Panels of various cytokines significantly increased in both subsets in the tonsil, blood and spleen postinoculation. Generally, the frequency of cDC expressing TNF- $\alpha$ markedly increased in the tonsil and spleen, and to a lesser extent in blood. Some cDC also started to express IFN- $\alpha$ after infection, especially in the tonsil. They increased their IL-12 expression in blood, then in the spleen. The number of $\mathrm{cDC}$ expressing IL-10 was remarkably high in the spleen. These results differed from previous in vitro studies that indicated that CSFV-infected mo-DC do not express any cytokine [13]. This discrepancy is discussed below. It has to be noticed that expression of IFN- $\alpha$ by porcine cDC was never demonstrated before but is in line with the constitutive expression of IFN- $\alpha$ by other porcine DC of myeloid origin, the Langerhans cells [6]. IFN- $\alpha$ expression by CD $172 \mathrm{a}^{+} \mathrm{CD} 11 \mathrm{~b}^{+} \mathrm{CD}^{-}{ }^{-} \mathrm{cDC}$ was also demonstrated in bovine lymph nodes after calf infection with bovine viral diarrhoea virus, another pestivirus [10].

Moreover, increasing percentages of $\mathrm{pDC}$ expressed IFN- $\alpha$, TNF- $\alpha$ and IL-12 in all studied tissues after infection. pDC preferentially expressed IFN- $\alpha$ in the tonsil, TNF- $\alpha$ in blood and IL-12 in blood and spleen, respectively. pDC also increased their IL-10 expression, but only in the spleen. In blood, jagged variations in frequencies of $\mathrm{pDC}$ expressing cytokines illustrated the $\mathrm{pDC}$ turnover presented above. These results were in agreement with cytokine production by in vitro CSFV-infected NIPC $[4,42]$. Moreover, porcine blood-isolated NIPC secreted IFN- $\alpha$, TNF- $\alpha$ and IL-12, but not IL-10, after CpGoligonucleotide stimulation [20].

The correlation between increasing frequencies of DC expressing cytokines and cytokine production levels in serum was interesting. As a consequence of the huge amounts of DC expressing IFN- $\alpha$ and TNF- $\alpha$ in secondary lymphoid organs and blood after infection, IFN- $\alpha$ and TNF- $\alpha$ productions in serum were uncommonly high, in accordance with previous reports [36, 43]. By contrast, IL-12 level remained constant in serum after infection, probably because of the high IFN- $\alpha$ concentration known to inhibit IL-12 production [2]. IL-6 was also transiently detected at $96 \mathrm{hpi}$. 
It proved impairment in this proinflammatory cytokine induction, known to be a better marker of bacterial infection in pigs [18].

As previously noticed, the discrepancy between our data that revealed maturation and activation of $\mathrm{cDC}$, and results from previous in vitro studies indicating that CSFV-infected mo-DC did neither mature nor express any cytokine [13] was intriguing, whereas these in vitro-derived cells were able to produce TNF$\alpha$ or IFN- $\alpha$ after mRNA transfection [15]. Other in vitro investigations showed that CSFV also disrupted secretion of IFN- $\alpha$ and proinflammatory cytokines in porcine aortic and kidney endothelial cell lines [7, 11]. It is to emphasize that CSFV-infected mo-DC were able to mature only when TNF- $\alpha$ and IFN- $\alpha$ were added into culture medium [13]. A recent in vitro study showed that TNF- $\alpha$ and IFN- $\alpha$ produced by porcine NIPC were closely involved in inducing maturation and activation of $\mathrm{cDC}$ [21]. Altogether, these data support our findings and lead to think about a close cooperation between DC subsets after CSFV infection. Thus, IFN- $\alpha$ and TNF- $\alpha$ expressions by pDC would be involved in induction of innate antiviral responses as well as in cDC stimulation. Subsequently, mature and activated DC subsets would then be involved in induction of adaptive immune responses, illustrated by punctual IFN- $\gamma$ and IL-18 secretions in serum. This was in agreement with CTL stimulation by CSFV-infected mature mo-DC [14] and with the initiation of cellular immune responses described in pigs surviving infection [35]. Additionally, the fact that high proportions of both DC subsets expressed IL10 in the spleen could reflect the starting of humoral immune response, in accordance with the detection of secreting IgM E2 ${ }^{+}$B cells the first days post-infection [39].

However, regarding their production of large amounts of TNF- $\alpha$ and IFN- $\alpha$, DC could be involved in induction of the lymphocyte apoptosis described in the thymus, spleen, lymph nodes and blood [41, 44]. Indeed, TNF- $\alpha$ and IFN- $\alpha$ can have adverse effects when produced in huge amounts after viral infection [32]. Thus, it was suggested that TNF- $\alpha$ secreted by CD $172 \mathrm{a}^{+}$cells, together with IL-1, IL-6 and prostaglandin, were responsible for apoptosis in non-infected immune system cells in lymphoid organs [16,24, 38]. These authors implicated macrophages as TNF- $\alpha$ producing cells, but our data showed that DC could also play a role in this phenomenon. Similarly, the high IFN- $\alpha$ level in serum was recently correlated to leucopoenia [43]. As described in other viral infections, IFN- $\alpha$ and TNF- $\alpha$ expressions by pDC could have an inhibitory effect in IL-12 expression by $\mathrm{cDC}$ becoming unable to induce efficient cellular immune responses [2]. IL-10 expression in $\mathrm{cDC}$ was also shown to stimulate the inhibition of both DC subset functions $[17,46]$.

In conclusion, CSFV infection induced DC recruitment and activation in secondary lymphoid organ T-cell areas during the first hours post-infection, leading to the initiation of innate immune responses, via IFN- $\alpha$ and TNF- $\alpha$ productions. IL-10 and IL-12 expressed by splenic DC participated in the induction of the known adaptive immune responses to CSFV $[37,38,39]$. However, the uncommonly high levels of cytokines could also play a role in disrupting immune system cells, either inducing apoptosis and/or impairing DC maturation and $\mathrm{T}$ cell priming.

Acknowledgements. Agnès Jamin was granted a $\mathrm{PhD}$ fellowship by AFSSA. We are grateful to all the staff of the Swine Virology Immunology unit (AFSSA, Ploufragan, France) for their contribution in sample collection during experimental assays. We thank JeanClaude Rault, Bernard Beaurepaire and Bruno Jan from the Section of Healthy Pig Production and Experimentation (AFSSA, Ploufragan, France) for pig routine bleeding and slaughtering. We are indebted to Stéphanie Bougeard (AFSSA, Ploufragan, France) for her advice in statistical analyses and to Elisabeth Repérant (AFSSA, Ploufragan, France) for improving the English language.

\section{REFERENCES}

[1] Asselin-Paturel C., Brizard G., Pin J.J., Briere F., Trinchieri G., Mouse strain differences in plasmacytoid dendritic cell frequency and function revealed by a novel monoclonal antibody, J. Immunol. (2003) 171:6466-6477.

[2] Asselin-Paturel C., Trinchieri G., Production of type I interferons: plasmacytoid dendritic cells and beyond, J. Exp. Med. (2005) 202:461-465.

[3] Aulitzky W.E., Tilg H., Vogel W., Aulitzky W., Berger M., Gastl G., Herold M., Huber C., Acute 
hematologic effects of interferon alpha, interferon gamma, tumor necrosis factor alpha and interleukin 2, Ann. Hematol. (1991) 62:25-31.

[4] Balmelli C., Vincent I.E., Rau H., Guzylack-Piriou L., McCullough K., Summerfield A., Fc gamma RIIdependent sensitisation of natural interferon-producing cells for viral infection and interferon-alpha responses, Eur. J. Immunol. (2005) 35:2406-2415.

[5] Banchereau J., Steinman R.M., Dendritic cells and the control of immunity, Nature (1998) 392:245-252.

[6] Bautista E.M., Ferman G.S., Gregg D., Brum M.C., Grubman M.J., Golde W.T., Constitutive expression of alpha interferon by skin dendritic cells confers resistance to infection by foot-and-mouth disease virus, J. Virol. (2005) 79:4838-4847.

[7] Bensaude E., Turner J.L., Wakeley P.R., Sweetman D.A, Pardieu C., Drew T.W., Wileman T., Powell P.P., Classical swine fever virus induces proinflammatory cytokines and tissue factor expression and inhibits apoptosis and interferon synthesis during the establishment of long-term infection of porcine vascular endothelial cells, J. Gen. Virol. (2004) 85:1029-1037.

[8] Bimczok D., Rothkotter H.J., Lymphocyte migration studies, Vet. Res. (2006) 37:325-338.

[9] Binns R.M., Pabst R., Lymphoid tissue structure and lymphocyte trafficking in the pig, Vet. Immunol. Immunopathol. (1994) 43:79-87.

[10] Brackenbury L.S., Carr B.V., Stamataki Z., Prentice H., Lefevre E.A., Howard C.J., Charleston B., Identification of a cell population that produces alpha/beta interferon in vitro and in vivo in response to noncytopathic bovine viral diarrhea virus, J. Virol. (2005) 79:7738-7744.

[11] Campos E., Revilla C., Chamorro S., Alvarez B., Ezquerra A., Dominguez J., Alonso F., In vitro effect of classical swine fever virus on a porcine aortic endothelial cell line, Vet. Res. (2004) 35:625-633.

[12] Carrasco C.P., Rigden R.C., Schaffner R., Gerber H., Neuhaus V., Inumaru S., Takamatsu H., Bertoni G., McCullough K.C., Summerfield A., Porcine dendritic cells generated in vitro: morphological, phenotypic and functional properties, Immunology (2001) 104:175-184.

[13] Carrasco C.P., Rigden R.C., Vincent I.E., Balmelli C., Ceppi M., Bauhofer O., Tache V., Hjertner B., McNeilly F., van Gennip H.G., McCullough K.C., Summerfield A., Interaction of classical swine fever virus with dendritic cells, J. Gen. Virol. (2004) 85:1633-1641.

[14] Ceppi M., de Bruin M.G., Seuberlich T., Balmelli C., Pascolo S., Ruggli N., Wienhold D., Tratschin J.D., McCullough K.C., Summerfield A., Identification of classical swine fever virus protein E2 as a target for cytotoxic $\mathrm{T}$ cells by using mRNA-transfected antigenpresenting cells, J. Gen. Virol. (2005) 86:2525-2534.
[15] Ceppi M., Ruggli N., Tache V., Gerber H., McCullough K.C., Summerfield A., Double-stranded secondary structures on mRNA induce type I interferon (IFN alpha/beta) production and maturation of mRNA-transfected monocyte-derived dendritic cells, J. Gene Med. (2005) 7:452-465.

[16] Choi C., Hwang K.K., Chae C., Classical swine fever virus induces tumor necrosis factor-alpha and lymphocyte apoptosis, Arch. Virol. (2004) 149:875889.

[17] Commeren D.L., VanSoest P.L., Karimi K., Lowenberg B., Cornelissen J.J., Braakman E., Paradoxical effects of interleukin-10 on the maturation of murine myeloid dendritic cells, Immunology (2003) 110:188-196.

[18] Fossum C., Cytokines as markers for infections and their effect on growth performance and well-being in the pig, Domest. Anim. Endocrinol. (1998) 15:439444.

[19] Gomez-Villamandos J.C., Ruiz-Villamor E., Bautista M.J., Sanchez C.P., Sanchez-Cordon P.J., Salguero F.J., Jover A., Morphological and immunohistochemical changes in splenic macrophages of pigs infected with classical swine fever, J. Comp. Pathol. (2001) 125:98-109.

[20] Guzylack-Piriou L., Balmelli C., McCullough K.C., Summerfield A., Type-A CpG oligonucleotides activate exclusively porcine natural interferonproducing cells to secrete interferon-alpha, tumour necrosis factor-alpha and interleukin-12, Immunology (2004) 112:28-37.

[21] Guzylack-Piriou L., Piersma S., McCullough K., Summerfield A., Role of natural interferon-producing cells and $\mathrm{T}$ lymphocytes in porcine monocytederived dendritic cell maturation, Immunology (2006) 118:78-87.

[22] Haverson K., Bailey M., Stokes, C.R., Simon A., LeFlufy L., Banfield G., Chen Z., Hollemweguer E., Ledbetter J.A., Monoclonal antibodies raised to human cells-specificity for pig leukocytes, Vet. Immunol. Immunopathol. (2001) 80:175-186.

[23] Jamin A., Gorin S., Le Potier M.F., Kuntz-Simon G., Characterization of conventional and plasmacytoid dendritic cells in swine secondary lymphoid organs and blood, Vet. Immunol. Immunopathol. (2006) 114:224-237.

[24] Knoetig S.M., Summerfield A., SpagnuoloWeaver M., McCullough K.C., Immunopathogenesis of classical swine fever: role of monocytic cells, Immunology (1999) 97:359-366.

[25] Le Potier M.F., Mesplède A., Vannier P., Classical swine fever and others Pestivirus, in: Straw B.E., Zimmerman J.J., D’Allaire S., Taylor D.J. (Eds.), Diseases of Swine, 9th ed., Blackwell Publishing, Ames, 2006, pp. 309-322. 
[26] Mayer D., Thayer T.M., Hofmann M.A., Tratschin J.D., Establishment and characterisation of two cDNA-derived strains of classical swine fever virus, one highly virulent and one avirulent, Virus Res. (2003) 98:105-16.

[27] McGoldrick A., Lowings J.P., Ibata G., Sands J.J., Belak S., Paton D.J., A novel approach to the detection of classical swine fever virus by RT-PCR with a fluorogenic probe (TaqMan), J. Virol. Methods (1998) 72:125-135.

[28] McGoldrick A., Bensaude E., Ibata G., Sharp G., Paton D.J., Closed one-tube reverse transcription nested polymerase chain reaction for the detection of pestiviral RNA with fluorescent probes, J. Virol. Methods (1999) 79:85-95.

[29] Mittelholzer C., Moser C., Tratschin J.D., Hofmann M.A., Generation of cytopathogenic subgenomic RNA of classical swine fever virus in persistently infected porcine cell lines, Virus Res. (1997) 51:125-137.

[30] Mittelholzer C., Moser C., Tratschin J.D., Hofmann M.A., Analysis of classical swine fever virus replication kinetics allows differentiation of highly virulent from avirulent strains, Vet. Microbiol. (2000) 74:293-308.

[31] Paillot R., Laval F., Audonnet J.C., Andreoni C., Juillard V., Functional and phenotypic characterization of distinct porcine dendritic cells derived from peripheral blood monocytes, Immunology (2001) 102:396-404.

[32] Palmer D.R., Sun P.F., Celluzzi C., Pang S.N., Sun W., Marovich M.A., Burgess T., Differential effects of dengue virus on infected and bystander dendritic cells, J. Virol. (2005) 79:2432-2439.

[33] Park C.S., Choi Y.S., How do follicular dendritic cells interact intimately with B cells in the germinal centre? Immunology (2005) 114:2-10.

[34] Pauly T., Konig M., Thiel H.J., Saalmuller A., Infection with classical swine fever virus: effects on phenotype and immune responsiveness of porcine $\mathrm{T}$ lymphocytes, J. Gen. Virol. (1998) 79:31-40.

[35] Piriou L., Chevallier S., Hutet E., Charley B., Le Potier M.F., Albina E., Humoral and cell-mediated immune responses of $\mathrm{d} / \mathrm{d}$ histocompatible pigs against classical swine fever (CSF) virus, Vet. Res. (2003) 34:389-404.

[36] Sanchez-Cordon P.J., Romanini S., Salguero F.J., Nunez A., Bautista M.J., Jover A., Gomez-Villamandos
J.C., Apoptosis of thymocytes related to cytokine expression in experimental classical swine fever, J. Comp. Pathol. (2002) 127:239-248.

[37] Sanchez-Cordon P.J., Nunez A., Salguero F.J., Carrasco L., Gomez-Villamandos J.C., Evolution of $\mathrm{T}$ lymphocytes and cytokine expression in classical swine fever (CSF) virus infection, J. Comp. Pathol. (2005) 132:249-260.

[38] Sanchez-Cordon P.J., Nunez A., Salguero F.J., Pedrera M., Fernandez de Marco M., GomezVillamandos J.C., Lymphocyte apoptosis and thrombocytopenia in spleen during classical swine fever: role of macrophages and cytokines, Vet. Pathol. (2005) 42:477-488.

[39] Sanchez-Cordon P.J., Romero-Trevejo J.L., Pedrera M., Raya A.I., Gomez-Villamandos J.C., The role of $\mathrm{B}$ cells in the immune response to pestivirus (classical swine fever virus), J. Comp. Pathol. (2006) 135:32-41.

[40] Sato M., Mikami O., Kobayashi M., Nakajima Y., Apoptosis in the lymphatic organs of piglets inoculated with classical swine fever virus, Vet. Microbiol. (2000) 75:1-9.

[41] Summerfield A., Knotig S.M., McCullough K.C., Lymphocyte apoptosis during classical swine fever: implication of activation-induced cell death, J. Virol. (1998) 72:1853-1861.

[42] Summerfield A., Guzylack-Piriou L., Schaub A., Carrasco C.P., Tache V., Charley B., McCullough K.C., Porcine peripheral blood dendritic cells and natural interferon-producing cells, Immunology (2003) 110:440-449.

[43] Summerfield A., Alves M., Ruggli N., de Bruin M.G., McCullough K.C., High IFN-alpha responses associated with depletion of lymphocytes and natural IFN-producing cells during classical swine fever, J. Interferon Cytokine Res. (2006) 26:248-255.

[44] Susa M., Konig M., Saalmuller A., Reddehase M.J., Thiel H.J., Pathogenesis of classical swine fever: B-lymphocyte deficiency caused by hog cholera virus, J. Virol. (1992) 66:1171-1175.

[45] Van Regenmortel M.H.V., Fauquet C.M., Bishop D.H.L, Virus taxonomy, in: Classification and Nomenclature of Viruses, 7th Report of the international committee on taxonomy of viruses, Academic Press, San Diego CA, 2005, pp. 867-872.

[46] Zou W., Borvak J., Wei S., Isaeva T., Curiel D.T., Curiel T.J., Reciprocal regulation of plasmacytoid dendritic cells and monocytes during viral infection, Eur. J. Immunol. (2001) 31:3833-3839. 